\title{
Behaviors and Attitudes of Effective Foreign Language Teachers: Results of a Questionnaire Study
}

Teresa R. Bell

University of Oklahoma

\begin{abstract}
This article reports on a study of teacher perceptions concerning teaching behaviors and attitudes that contribute to effective foreign language teaching and learning. The data were collected by means of a questionnaire to which 457 postsecondary foreign language teachers of French, German, and Spanish who are members of ACTFL responded. Based on current research on second language acquisition (SLA), various teaching behaviors and attitudes of effective foreign language teachers were identified for inclusion on the questionnaire. The results indicate an emerging professional consensus regarding a number of teacher behaviors and attitudes related to foreign language teaching. The more that is known about teacher beliefs, the more likely the profession will be to create models for foreign language teacher preparation and evaluation that reflect relevant behaviors and attitudes of foreign language teaching.
\end{abstract}

Key words: applied linguistics, effective foreign language teaching, questionnaire research, SLA (second language acquisition), teacher behaviors

Languages: French, German, Spanish

\section{Introduction}

In the last 50 years, many researchers and professionals responsible for teacher development and evaluation have sought to establish criteria for assessing effective teaching. While there is little agreement regarding which specific behaviors constitute effective teaching, researchers agree at least on some dimensions that describe effective teaching in general, regardless of subject matter. These include enthusiasm/expressiveness, clarity of explanation, and rapport/interaction (Murray, 1991). Researchers also agree that teaching is multidimensional, and that even though these dimensions may vary according to setting and discipline, they are still consistent to some degree across disciplines.

Very little research has been conducted regarding discipline-specific teaching behaviors and attitudes of teachers (Brosh, 1996; Schulz, 2000). Because every teaching and learning situation is context specific and because disciplines differ, some teaching behaviors and attitudes are considered more relevant in one discipline than in another (Murray \& Renaud, 1995). For example, lecturing may be effective in a history course but not in a beginning foreign language course. Yet, in most cases, the history teacher and foreign language teacher might be evaluated using exactly the same criteria (Sternberg \& Horvath, 1995). Thus, while some teaching behaviors are considered to be effective regardless of discipline, there are also teaching behaviors and attitudes that are considered to be discipline specific.

As stated above, the research literature suggests that there is no one single accepted definition of effective foreign language teaching. Foreign language teaching is a complex, multi-

Teresa R. Bell (PhD, University of Arizona) is Assistant Professor of Second Language Acquisition and Foreign Language Pedagogy at the University of Oklahoma, Norman, Oklahoma. 
dimensional process that means different things to different people. For the purpose of this study, the definition of effective foreign language teaching is clear and enthusiastic teaching that provides learners with the grammatical (syntactical and morphological), lexical, phonological, pragmatic, and sociocultural knowledge and interactive practice they need to communicate successfully in the target language. To this end, this study first identified teaching behaviors and attitudes that are specific to foreign language teaching. It then identified teaching behaviors and teacher attitudes that are perceived by postsecondary foreign language teachers to be particularly effective in foreign language teaching. ${ }^{1}$

\section{Recent Trends in Foreign Language Teaching}

Current trends in the way foreign languages are taught provide insight into teaching behaviors and attitudes that foreign language teachers and researchers believe to be effective. During the past two decades, a shift in foreign language teaching from traditional grammar-based approaches to more communicative and interactive approaches has brought new changes in the ways foreign languages are taught. Recent trends in foreign language teaching that reflect these shifts include: communicative language teaching (Lee \& VanPatten, 2003; Nunan, 1989; Savignon, 1998), computer-assisted language learning (Bush \& Terry, 1997; Dunkel, 1991; Lafford \& Lafford, 1997; Pennington, 1996), the Standards for Foreign Language Learning (National Standards, 1999), teaching culture (Galloway, 1985; Kramsch, 1993a, 1993b; Lange, 1999), content-based instruction (Bragger \& Rice, 1998; Genessee, 1998; Leaver \& Stryker, 1989), languages for specific purposes (Douglas, 1999; MacKay \& Palmer, 1981), courses for heritage learners (Merino, Trueba, \& Samaniego, 1993; Reber \& Geeslin, 1998; Valdés, 1995), focus on form in classroom second language acquisition (SLA) (Doughty \& Williams, 1998), and authentic assessment (Hancock, 1994; Liskin-Gasparro, 1996; Moore, 1994; Stansfield, 1994; Wiggins, 1989, 1993, 1994).

The recent discussion of the role of grammar in the communicative classroom may be motivated in part by upto-date research in SLA and teaching theories. For example, according to the grammar-translation method of the late 19th and early 20th centuries, grammatical analysis and rule learning were the object of foreign language study (see Larsen-Freeman, 1986; Richards \& Rodgers, 1986). The audiolingual method, strongly influenced by B. F. Skinner's behaviorist view of learning, favored habit-forming grammar learning to explicit learning (Lado, 1964; Skinner, 1957). Krashen's monitor model (Krashen, 1981) recognizes the importance of subconscious acquisition of the target language and emphasizes that conscious learning of grammar rules does not lead to successful SLA. Other the- ories of and approaches to foreign language teaching such as community language learning (Curran, 1976; 1982), the "silent way" (Gattegno, 1972), "suggestopedia" (Lozanov, 1978), total physical response (Asher, 1986), the natural approach (Krashen \& Terrell, 1983), the notions of "communicative competence" (Savignon, 1983) and "proficiency" (Buck, Byrnes, \& Thompson, 1989), and processing instruction (VanPatten, 1992) have continued to either emphasize or deemphasize the role of grammar instruction in the foreign language classroom. More recently, the research on "focus on form" in the foreign language classroom (Doughty \& Williams, 1998) has sought to redefine foreign language teaching in the context of focusing on one specific grammatical feature while simultaneously attending to the meaning of the utterance.

The shift in foreign language teaching from grammar based to communicative and recent focus-on-form/communicative approaches calls for updated models for evaluating foreign language teaching. The foreign language teaching profession has sought over the past few years to create guidelines that describe a qualified foreign language teacher (AATF, 1989; AATSP, 1990; ACTFL, 1988; Schulz, Anderson, Bernhardt, Byrnes, Cothrun, Dial, et al., 1993). Schrier and Hammadou (1994) asserted that in order to evaluate effective foreign language teaching, attributes of effective teaching should first be identified on repeated occasions, should be agreed upon by foreign language teachers as being worth evaluating, and should be proved worthwhile in many settings.

\section{Call for Research}

A fundamental assumption in teacher evaluation is that effective teaching behaviors are identifiable, stable, and reasonably consistent in their effects on students across contexts (Andrews \& Barnes, 1990). Further, teacher evaluation can be considered valid if it follows the properly delineated steps to (a) seek to identify effective teaching behaviors, and (b) come to a consensus in the profession regarding which of the identified behaviors teachers consider worth evaluating (Schrier \& Hammadou, 1994; Schulz, 2000). With these assumptions in mind, the first step in identifying good teaching behaviors in foreign language teaching is to look at theoretical models of SLA and the research that has been conducted to test these models in the classrooms. The results of empirical research studies should point us in the direction of identifying teaching behaviors that may contribute to successful learning. If foreign language teachers are able to provide learners with activities that reflect successful results of research studies, the behaviors used by successful teachers in providing these experiences for learners would be identified as effective teaching behaviors.

The second step in establishing criteria for foreign language teacher evaluation would be to find out which of 
these teaching behaviors are perceived by teachers to be effective in successful foreign language learning. Many factors of teaching cannot be empirically researched due to the vast variety found in teaching styles as well as in teaching contexts. For this reason, we depend on a professional consensus to know what constitutes good teaching.

This exploratory study identified effective teaching behaviors reported in the professional literature and collected opinions regarding these behaviors from postsecondary foreign language teachers. Professional consensus was investigated by means of a questionnaire. Teachers were asked to rate observable teaching behaviors or attitudes of foreign language teachers as to their effectiveness in teaching as well as to react to theoretical statements that explain SLA in general or in a classroom context.

\section{Research Questions}

What constitutes effective foreign language teaching has been a topic of discussion ever since foreign languages entered the school curriculum (Schulz, 1988, 2000). Although professional organizations concerned with improving foreign language teaching have issued standards for foreign language teaching and learning in the attempt to improve the quality of foreign language teaching in the United States, most of the standards that are advocated for effective foreign language teaching are based almost entirely on research conducted in non-discipline-specific domains of general education. Some of these standards include: leadership skills, professional abilities, communication, sensitivity to diverse student populations, and commitment to lifelong professional development (see AATF, 1989; AATSP, 1990; ACTFL, 1988; Schulz et al., 1993). The only standards that are related to foreign language teaching state that the teacher should be able to use the foreign language proficiently and should be able to teach about the target culture. Other teaching behaviors that are specific to foreign language teaching are not sufficiently described or evaluated.

Given the researcher's specific interest in investigating behaviors and attitudes of effective foreign language teachers, the following major research questions were formulated:

1. What are the salient issues in the research literature in SLA and foreign language learning that can be modified or directly applied to effective foreign language teaching perspectives in the classroom context?

2. To what extent do postsecondary foreign language teachers agree on behaviors or attitudes that are believed to contribute to effective foreign language teaching and learning?

Taking these research questions as a point of departure, salient items in the research literature in SLA and foreign language teaching, related to effective foreign language teaching, were identified for inclusion on the ques- tionnaire. Space does not permit a detailed review of the literature regarding the theoretical tenets or teaching behaviors identified in this study. The interested reader will find pertinent references in the original dissertation study (Reber, 2001).

\section{Method}

Questionnaire research was considered an appropriate form of data collection to explore teachers' beliefs about effective foreign language teaching and learning. The questionnaire was developed by the researcher and contained 80 items that covered the following categories relevant to SLA and foreign language teaching (some items fit into more than one category): (a) learning objectives related to the Standards for Foreign Language Learning (National Standards, 1999) (17 items); (b) corrective feedback (7 items); (c) theories and teacher behaviors related to communicative approaches (27 items); (d) focus on form in classroom SLA (10 items); (e) individual learner differences in foreign language learning ( 7 items); ( $f$ ) strategies for foreign language learning (4 items); (g) theories about SLA (5 items); (h) teacher qualifications (6 items); and (i) assessment in foreign language teaching (8 items). The questionnaire is divided into two parts. Part One contains items regarding observable behaviors of effective foreign language teachers (see Table 1). Part Two of the questionnaire contains theoretical statements regarding attitudes about SLA and foreign language teaching and learning (see Table 2). Respondents were asked to rate each item on a Likert-type scale from 1 (strongly disagree) to 5 (strongly agree) as to how much it contributes to effective foreign language teaching.

As each questionnaire item is discussed in this study, it is designated with either "B" (for behavior-related items that appear in Part One of the questionnaire) or "T" (for theory-related items that appear in Part Two of the questionnaire) as well as the number of the item as it appeared on the questionnaire. The 80 items on the questionnaire appeared in random order, not according to category. Respondents were assured in the introduction to the questionnaire that their responses would be kept confidential. The questionnaire used in this study was constructed to be computer scanned to determine frequencies of responses.

\section{Respondents}

From the ACTFL mailing list, 1,000 names of postsecondary teachers of French, German, and Spanish were randomly selected, and questionnaires were mailed to these individuals. The researcher selected teachers of French, German, and Spanish because much of the classroombased research on foreign language learning has been conducted in classrooms where these languages are being taught. Four hundred fifty-seven completed questionnaires were returned, resulting in a response rate of $45.7 \%$. 
Questionnaire Item

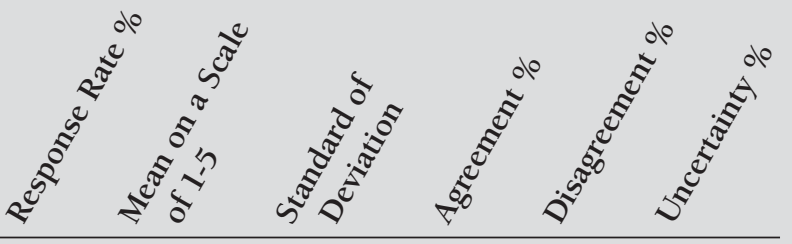

The effective foreign language teacher..

B11) shows personal involvement in or enthusiasm for the TL and culture.

B40) uses the TL competently.

98.5

4.89

$.39 \quad 99.4$

$\begin{array}{ll}.6 & 0 \\ .9 & 1\end{array}$

B06) bases at least some part of students' grades on their actual use of the TL.

98.0

$\begin{array}{lll}4.76 & .53 & 97.0\end{array}$

98.5

4.67

$.55 \quad 97.8$

$.4 \quad 1.8$

B47) frequently uses authentic materials and realia (e.g., maps, pictures, artifacts, items of clothing, foods) to illustrate features of the TL and culture.

B04) uses small groups to help learners experience a greater degree of involvement.

B27) uses the TL as the predominant means of classroom

communication.

B10) adjusts learning activities to meet the needs of foreign

language students with a variety of interests.

B14) varies learning activities of foreign language instruction depending on learners' ages.

B05) gives learners a time limit to complete small group activities.

B28) provides learners with concrete tasks to complete while reading or listening to texts in the TL.

B44) provides opportunities for students to use the TL both within

and beyond the school setting.

B13) teaches foreign language students to use various learning

strategies (i.e., self-evaluation, repetition, imagery, etc.).

$\begin{array}{llllll}98.5 & 4.64 & .58 & 97.0 & 1.8 & 1.2\end{array}$

B32) teaches idiomatic expressions and language routines to help

learners successfully engage in conversations in the TL.

$\begin{array}{llllll}98.2 & 4.61 & .64 & 96.4 & 1.8 & 1.8\end{array}$

B34) encourages foreign language learners to speak in the TL

beginning the first day of class.

97.8

97.8

4.56

$.67 \quad 94.0$

$3.5 \quad 2.5$

98.7

4.45

$\begin{array}{lll}.62 & 94.7 & 4.6\end{array}$

.07

B08) uses student-student role play situations from the beginning of elementary language instruction.

B41) provides opportunities for students to reinforce and further their knowledge of other disciplines through the foreign language.

B03) uses information gap activities (where students have to find out unknown information from a classmate or another source).

98.0

98.0

4.44

$\begin{array}{ll}.76 & 90.2\end{array}$

$\begin{array}{ll}7.2 & 2.6\end{array}$

97.8

4.41

$.68 \quad 92.6$

$5.9-1.5$

98.7

4.40

$.69 \quad 94.0$

3.9

2.1

98.0

4.39

$.63 \quad 92.0$
.

$\begin{array}{ll}6.6 & 1.4\end{array}$

98.5

4.38

$.67 \quad 91.3$

7.7

$\begin{array}{ll}6.7 & 1.0\end{array}$

97.4

4.34

$\begin{array}{ll}.65 & 93.0\end{array}$

3.9

3.1

97.8

4.28

.88

$.88 \quad 86.0$

7.9

6.1

$\begin{array}{llllll}98.9 & 4.28 & .87 & 85.4 & 9.4 & 5.2\end{array}$

98.0

98.0

4.26

$.72 \quad 89.10 .060$

97.2

4.25

89.0

8.

$8.1 \quad 2.9$

B29) teaches foreign language students to use strategies to improve their vocabulary learning (e.g., memory devices or creating a mental image of the word).

B09) encourages students to express and discuss their needs and preferences for language learning.

B31) devotes class time to giving examples of cultural differences between target and student's native language use.

$\begin{array}{llllll}98.0 & 4.21 & .74 & 85.0 & 12.5 & 2.5\end{array}$

$\begin{array}{llllll}98.2 & 4.15 & .80 & 83.3 & 12.3 & 4.4\end{array}$

B46) integrates computer-aided instruction (e.g., computer-based exercises, e-mail, the Internet, CD-ROM, etc.) into foreign language teaching.

B42) selects materials that present distinctive viewpoints that are available only through the foreign language and its cultures.

$\begin{array}{lllllll}97.8 & 4.10 & .84 & 85.0 & 7.7 & 7.3\end{array}$

B26) has students act out commands or engage in other physical activity given by the teacher to practice listening comprehension in the TL.

$\begin{array}{llllll}98.2 & 4.09 & .80 & 83.0 & 12.0 & 5.0\end{array}$

$\begin{array}{llllll}97.8 & 4.08 & .76 & 80.0 & 16.4 & 3.6\end{array}$

4.08

$.77 \quad 82.6$

82.6

13.1

4.3 


\section{Table 1 (cont.)}

\section{TOTAL TABULAR RESPONSES TO PART ONE OF THE QUESTIONNAIRE}

Questionnaire Item

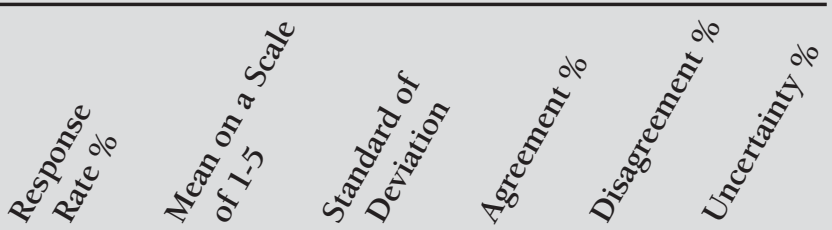

The effective foreign language teacher...

B39) understands the fundamentals of linguistic analysis

(phonology, syntax) as they apply to the TL.

$\begin{array}{llllll}97.2 & 4.06 & .95 & 80.0 & 9.8 & 10.2\end{array}$

B15) uses activities and assignments that draw learners' attention

to specific grammatical features.

B07) bases at least some part of students' grades on completion

of assigned tasks.

$\begin{array}{llllll}98.2 & 4.06 & .87 & 84.2 & 8.1 & 7.7\end{array}$

B20) teaches appropriate hesitation or other discourse strategies

to help learners gain time in conversational exchanges.

$\begin{array}{llllll}98.5 & 4.03 & .89 & 78.7 & 13.6 & 7.7\end{array}$

B23) uses recasts (correct reformulations of students' speech) as a preferred method of corrective feedback.

$\begin{array}{llllll}98.2 & 3.96 & .81 & 74.6 & 4.1 & 20.8\end{array}$

B43) provides opportunities for students to demonstrate

understanding of the nature of language through comparisons

of the TL and their own.

B17) simplifies his or her TL output so students can understand what is being said.

$\begin{array}{llllll}98.5 & 3.96 & .85 & 80.0 & 7.0 & 12.9\end{array}$

B02) teaches new complex language structures only after less

complex structures have been introduced and practiced.

B19) teaches grammar inductively (i.e., gives examples before grammatical rules).

97.2

$\begin{array}{llllll}97.2 & 3.96 & .85 & 80.0 & 7.0 & 11.2\end{array}$

B12) permits learners to select their own topics for discussion.

$\begin{array}{llllll}97.4 & 3.87 & 1.01 & 76.0 & 13.9 & 10.1\end{array}$

B25) uses indirect cues or hints to signal errors to the learner

(such as, asking them if they are sure their response is correct or

using facial expressions or body language).

B21) exposes students to different dialects of the TL.

$\begin{array}{llllll}97.8 & 3.85 & 1.08 & 72.7 & 17.0 & 10.1\end{array}$

B16) uses activities where learners need to understand a certain grammatical feature to understand the meaning of spoken or written text.

$\begin{array}{llllll}98.2 & 3.83 & .90 & 72.2 & 9.0 & 18.4 \\ 97.6 & 3.73 & .82 & 67.7 & 8.5 & 23.0\end{array}$

B01) creates lesson plans that emphasize grammatical aspects of the TL.

B35) explains why learner responses are inaccurate when students make errors.

B30) presents grammar rules one at a time and has student practice examples of each rule before going on to another.

B36) allows students to write summaries or answer questions on reading or listening passages in English rather than the TL.

B24) corrects errors as soon as possible after they occur.

B18) thoroughly explains new grammar rules before asking students to practice the relevant structure.

97.6

B22) requires students to practice unfamiliar grammatical forms or patterns in substitution or transformation exercises.

B45) teaches grammar deductively (i.e., gives grammatical rule before examples).

B33) encourages learners to begin speaking in the TL only when they feel they are ready to.

B38) grades written language assignments predominantly for grammatical accuracy.

97.8

97.

3.71

$.95 \quad 70.5$

0.5

14.3

14.9

$\begin{array}{llllll}97.4 & 3.63 & 1.03 & 64.7 & 17.0 & 18.2\end{array}$

B37) grades spoken language production predominantly for grammatical accuracy. 97.

$\begin{array}{llllll}97.2 & 3.57 & 1.09 & 63.0 & 21.0 & 16.2\end{array}$

$\begin{array}{llllll}95.6 & 3.56 & 1.18 & 66.4 & 24.7 & 8.5\end{array}$

Note. $\mathrm{TL}=$ target language.

$\begin{array}{llllll}95.8 & 3.25 & 1.08 & 48.0 & 26.0 & 23.9\end{array}$

$\begin{array}{llllll}97.2 & 3.16 & 1.18 & 46.0 & 33.0 & 19.5\end{array}$

$\begin{array}{llllll}96.5 & 3.09 & 1.21 & 44.0 & 33.0 & 21.2\end{array}$

$\begin{array}{llllll}96.7 & 3.05 & 1.15 & 40.0 & 38.0 & 21.2\end{array}$

$\begin{array}{llllll}97.6 & 2.74 & 1.29 & 32.1 & 52.5 & 15.1\end{array}$

$\begin{array}{llllll}98.5 & 2.68 & 1.20 & 31.6 & 49.1 & 19.0\end{array}$

$\begin{array}{llllll}96.5 & 2.59 & 1.14 & 26.0 & 52.0 & 20.6\end{array}$

$\begin{array}{llllll}98.2 & 2.54 & 1.12 & 23.0 & 57.0 & 19.3\end{array}$

$\begin{array}{llllll}97.2 & 2.49 & 1.15 & 27.0 & 63.0 & 9.4\end{array}$

$\begin{array}{llllll}97.8 & 1.98 & .89 & 9.0 & 82.5 & 8.5\end{array}$


Questionnaire Item

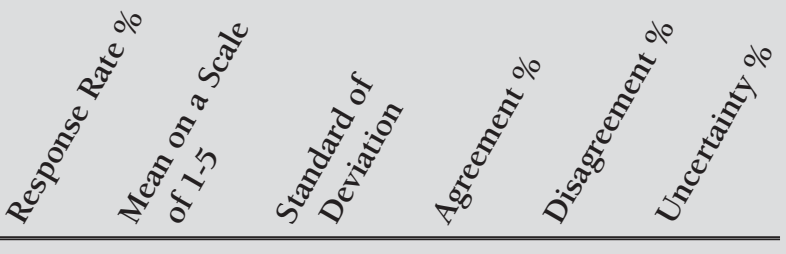

T15) Foreign language learners should interact with native

97.2

4.30

$.73 \quad 92.0$

3.4

4.6

speakers of the TL as often as possible.

T33) Familiarity with theories of SLA helps foreign language

97.8

4.22

$.88 \quad 87.5$

4.0

8.5

eachers teach better.

T22) Foreign language learners do not always learn grammatical structures by means of formal instruction.

97.2

4.13

$.59 \quad 91.0$

2.9

6.1

T06) Using small group activities is likely to reduce learner anxiety.

T29) Tests should imitate real-life language use situations

whenever possible.

T23) Activities that focus on the exchange of meaning between

two speakers are more important than activities that focus on

96.1

4.12

$.77 \quad 84.0$

97.2

4.09

$.84 \quad 84.0$

$4.0 \quad 12.0$

97.2

4.09

.9580 .0

8.4

11.6

the manipulation of grammatical forms.

T10) One of the most important things a foreign language teacher can do is reduce learner anxiety.

T16) Each person possesses certain subconscious knowledge

about language that allows him or her to learn a foreign language

to some degree.

T31) Portfolio assessment (a collection of student's work, such as, oral and written reports, creative projects, writings, etc.) can be used to validly and reliably measure student achievement in the foreign language.

T24) Aspects of the TL that are formally learned enable learners to

96.7

3.96

$.84 \quad 80.0$

7.0

11.8

96.5

3.80

.86

69.0

5.0

23.6

edit their TL speech for grammatical correctness.

T12) Using small group instruction is likely to enhance student self-correction.

T21) Foreign language learners acquire foreign language structures in a predictable order, whether the language is learned in a classroom or not.

T07) Grammatical structures that are formally taught are more difficult to use in natural communication than grammatical

structures that are learned in natural communication outside the classroom.

\begin{tabular}{|c|c|c|c|c|c|c|}
\hline $\begin{array}{l}\text { T26) Making the first occurrence of a new word memorable is } \\
\text { more important than practicing it several times. }\end{array}$ & 95.6 & 3.00 & 1.09 & 33.0 & 34.0 & 30.6 \\
\hline $\begin{array}{l}\text { T20) The learner who identifies with members of the target culture } \\
\text { group learns the TL more accurately than the learner who learns } \\
\text { the language for personal gain (i.e., monetary). }\end{array}$ & 96.7 & 2.98 & 1.02 & 30.0 & 33.0 & 34.4 \\
\hline $\begin{array}{l}\text { T05) A foreign language is learned predominantly by imitating } \\
\text { correct models of the language. }\end{array}$ & 95.0 & 2.94 & 1.14 & 41.0 & 41.0 & 19.0 \\
\hline $\begin{array}{l}\text { T03) Foreign language learners should be corrected when they } \\
\text { make grammatical mistakes. }\end{array}$ & 93.9 & 2.93 & 1.00 & 34.0 & 36.0 & 28.0 \\
\hline $\begin{array}{l}\text { T11) Most of the mistakes learners make are due to differences } \\
\text { between the TL and their native language. }\end{array}$ & 96.7 & 2.89 & 1.05 & 32.0 & 42.0 & 21.9 \\
\hline $\begin{array}{l}\text { T01) Adult learners will rarely, if ever, achieve native-like } \\
\text { proficiency in a foreign language. }\end{array}$ & 96.5 & 2.80 & 1.25 & 37.0 & 50.0 & 12.0 \\
\hline $\begin{array}{l}\text { T30) Testing students on what has been taught in class is more } \\
\text { important than testing their overall language development. }\end{array}$ & 94.1 & 2.58 & .94 & 17.0 & 53.0 & 28.0 \\
\hline
\end{tabular}
important than testing their overall language development. 


\section{Table 2 (cont.)}

TOTAL TABULAR RESPONSES TO PART TWO OF THE QUESTIONNAIRE (CONT.)

\section{Questionnaire Item}

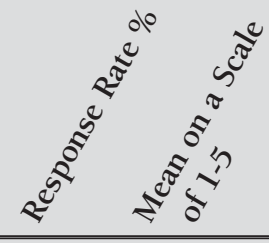

T04) Learning a foreign language "on the street" is generally more effective than learning it in the classroom.

\begin{tabular}{|c|c|c|c|c|c|c|}
\hline $\begin{array}{l}\text { T13) Foreign language learners should be put into groups of } \\
\text { fast and slow learners. }\end{array}$ & 96.3 & 2.52 & 1.05 & 20.0 & 57.0 & 21.7 \\
\hline $\begin{array}{l}\text { T18) The higher a person's IQ, the more likely he or she is to } \\
\text { learn a foreign language well. }\end{array}$ & 96.6 & 2.42 & .90 & 12.0 & 57.0 & 31.0 \\
\hline T08) It is essential to correct most errors. & 95.4 & 2.42 & 1.05 & 19.0 & 65.0 & 16.0 \\
\hline $\begin{array}{l}\text { T19) Using small group instruction is likely to cause students } \\
\text { to learn inaccurate forms of the TL from each other. }\end{array}$ & 97.6 & 2.37 & .86 & 13.0 & 67.3 & 19.7 \\
\hline $\begin{array}{l}\text { T14) Too much interaction with native speakers can hinder } \\
\text { beginning foreign language learners because native speakers } \\
\text { generally take control of conversations. }\end{array}$ & 96.1 & 2.36 & .98 & 14.0 & 63.5 & 22.5 \\
\hline $\begin{array}{l}\text { T17) Foreign language learners can learn to use a foreign } \\
\text { language proficiently by mere exposure to it (i.e., reading } \\
\text { in or listening to the language). }\end{array}$ & 96.5 & 2.35 & 1.05 & 17.0 & 67.2 & 15.8 \\
\hline $\begin{array}{l}\text { T09) Written and spoken language comprehensible to the learner } \\
\text { but slightly above the difficulty level of his or her productive } \\
\text { ability is all that is necessary for foreign language acquisition. }\end{array}$ & 95.4 & 2.31 & 1.01 & 14.0 & 70.7 & 15.3 \\
\hline $\begin{array}{l}\text { T27) The teacher's insistence on rapid speaking by learners } \\
\text { improves TL production. }\end{array}$ & 96.5 & 2.14 & .84 & 7.0 & 73.3 & 19.7 \\
\hline $\begin{array}{l}\text { T02) Adults learn a foreign language in a manner similar to } \\
\text { the way they learned their first language. }\end{array}$ & 97.2 & 2.12 & 1.00 & 13.0 & 77.2 & 9.8 \\
\hline $\begin{array}{l}\text { T32) Teaching about the target culture is not as important as } \\
\text { teaching grammar and vocabulary. }\end{array}$ & 96.3 & 1.93 & .84 & 7.0 & 83.0 & 8.3 \\
\hline $\begin{array}{l}\text { T28) Native or near-native language proficiency of the teacher } \\
\text { is more important than his or her teaching skills. }\end{array}$ & 97.4 & 1.88 & .77 & 3.0 & 86.3 & 10.7 \\
\hline $\begin{array}{l}\text { T25) Learners must understand every word of an oral message } \\
\text { to understand what is being said in the TL. }\end{array}$ & 97.4 & 1.43 & .68 & 2.0 & 96.5 & 1.5 \\
\hline
\end{tabular}

Note: $\mathrm{TL}=$ target language. 
Demographic information about participants was collected in the following areas: gender, age, level of and foreign language(s) taught, number of years taught, highest degree obtained, the number of pedagogy-related inservice activities attended, and pedagogy-related courses completed. The demographic information respondents provided sheds light on the postsecondary population of foreign language teachers and enrollment patterns in the United States. For instance, about one third of the respondents taught Spanish while about 19\% taught French, and 13\% taught German. Also, 38.7\% of all respondents taught or had taught a teaching methods course and had expertise in teaching methodology. Of all respondents, $72.8 \%$ had been teaching for 10 or more years, and almost half of the respondents reported 20 years or more teaching experience. Finally, $74.2 \%$ had completed a course in foreign language teaching methods, and $53.4 \%$ had completed a course in foreign language pedagogy other than the teaching methods course. This finding is not surprising, due to the fact that $43.6 \%$ of all respondents had taught at the K-12 level and were certified teachers. Only about one third of the respondents reported completing a course in testing or in curriculum development.

\section{Significant Results of the Study}

The results of this questionnaire study indicate that there is emerging professional consensus for more than half (56\%) of the teaching behaviors and attitudes related to foreign language teaching that appeared on the questionnaire with response rates of 4.0 and higher or 2.5 and lower on a Likert-type scale from 1 (strongly disagree) to 5 (strongly agree) as to how much each item contributes to effective foreign language teaching. ${ }^{2}$ (Results of all 80 items on the questionnaire are presented in Tables 1 and 2.) Generally speaking, there was strong positive agreement on all five of the Standards for Foreign Language Learning. Teachers also agreed with the majority of the items related to the following categories: qualifications of foreign language teachers; general theories and behaviors related to communicative theories of foreign language teaching, the importance of small group work, and negotiation of meaning; selected strategies in foreign language learning; and assessment.

Less agreement emerged in the following three categories: error correction, focus on grammatical form, and individual differences of foreign language learners. For all of the items related to error correction, at least $10 \%$ of all respondents were uncertain whether any of them contributed to effective foreign language teaching. These results may also reflect the conflicting theoretical positions taken by SLA scholars regarding corrective feedback (Chaudron, 1988; DeKeyser, 1993) as well as the inconsistent results reported in empirical studies as to whether or not explicit and/or error correction is beneficial to learners (Carroll \& Swain, 1993). It is evident from the four items that yielded neither majority agreement nor disagreement that the role, place, and type of error correction as well as the source of learner errors remain controversial topics in foreign language teaching and learning.

Respondents were also uncertain for 7 of the 10 items related to focus on grammatical form, and for 5 of the 7 items related to individual differences of foreign language learners. The rate of uncertainty among respondents on these items possibly reflects the research results in SLA that do not clearly define relationships between certain personality characteristics or individual factors and increased foreign language learning (Ellis, 1994; Mitchell \& Myles, 1998).

The most reassuring results of this study are that the 457 respondents were for the most part familiar with the pedagogical behaviors and attitudes included on the questionnaire. They appear to be informed members of the foreign language teaching profession who are interested in improving the teaching of foreign languages in the United States.

Finally, the most controversial results of this study are found in the results of six items $(7.5 \%$ of the total) that yielded very close rates of agreement and disagreement. Two items (out of seven total related to the topic) regarding error correction achieved very close rates of agreement and disagreement: (a) foreign language learners should be corrected when they make grammatical mistakes (T03) (34\% agreed, $36 \%$ disagreed, and 28\% were uncertain), and (b) the effective foreign language teacher corrects errors as soon as possible after they occur (B24) (40\% agreed, 38\% disagreed, and $21 \%$ were uncertain). Teachers' lack of agreement or disagreement with these items may reflect the experience teachers have had with error correction in their own classrooms regarding when and how error correction should be employed.

Two items pertaining to teacher behaviors or theories related to communicative approaches to foreign language teaching and learning also achieved very close rates of agreement and disagreement: (a) making the first occurrence of a word memorable is more important than practicing it several times (T26) (33\% agreed, 34\% disagreed, and 31\% were uncertain), and (b) grammatical structures that are formally taught are more difficult to use in natural communication than grammatical structures that are learned in natural communication outside the classroom (T07) (37\% agreed, 33\% disagreed, and $28 \%$ were uncertain).

Finally, two items related to theories about SLA also did not achieve majority agreement or disagreement: (a) a foreign language is learned predominantly by imitating correct models of the target language (T05) (41\% agreed, $41 \%$ disagreed, and $18.4 \%$ were uncertain); and (b) the learner who identifies with members of the target culture groups learn the target language more accurately than the learner 
who learns the language for professional gain (T20) (30\% agreed, 33\% disagreed, and 34.4\% were uncertain).

The fact that these items did not reach majority agreement or disagreement and that their rates of agreement and disagreement are so close implies that the categories that are represented by these items require further research.

\section{Summary and Implications}

It is important to keep in mind that while many behaviors of effective teachers are not discipline specific, there are certain behaviors that are specific to foreign language teaching. This study has found that a number of these are grounded in SLA research as well as in research on teacher effectiveness. As mentioned previously, in order to evaluate effective foreign language teaching, attributes of effective foreign language teaching must first be identified, must then be agreed upon as being worthy of evaluation by current foreign language teachers, must be identified on repeated occasions, and must be proved worthwhile in many settings (Schrier \& Hammadou, 1994). This study sought to undertake the first two steps necessary in evaluating effective foreign language teaching by (a) identifying effective classroom teaching behaviors and attitudes that have been found in the professional literature to facilitate foreign language learning, and (b) finding out which of these teaching behaviors and attitudes are perceived by postsecondary foreign language teachers to contribute to student learning.

For the nine categories of SLA and foreign language teaching represented in this study, there was strong majority agreement, and hence emerging professional consensus, on more than $50 \%$ of the items related to the Standards for Foreign Language Learning, theories related to communicative approaches to foreign language teaching, small group work, negotiation of meaning, strategies for foreign language learning, and teacher qualifications. There is still major uncertainty in the profession as to the place and role of error correction in foreign language teaching and learning, how and when focus on grammatical form should be implemented, and the effects of learning differences among individual learners. From the results of this study, it is evident that those categories which elicited uncertain responses require further research and should be dealt with extensively in teacher development courses by making prospective teachers aware of various possible strategies for employing corrective feedback, teaching grammar, and varying teaching methods to accommodate individual learning needs of language learners.

\section{Limitations of This Study}

Some weaknesses of this study should be noted. First, respondents were limited to postsecondary foreign language teachers. This study focused on beliefs of postsecondary teachers for three reasons: (a) much of the research in SLA and foreign language teacher preparation has been conducted in adult foreign language classrooms; (b) the researcher's own interest and experience is in the area of postsecondary foreign language teaching and teacher development, and (c) funding was granted only if the respondents were postsecondary teachers. Including teachers at other levels would have added validity to the results.

Other limitations of this study were related to questionnaires as a means of data collection. First, questionnaires can be difficult to construct. It is possible that the wording of some items may have been unclear and that respondents either simply did not respond to an item they did not understand or marked it "uncertain." Another limitation of questionnaire research concerns the issue of using strictly quantitative research in a study regarding behaviors and attitudes. If the questionnaire had contained an open-ended component, respondents would have been able to express their opinions about particular items and explain why they agreed or disagreed with a certain behavior or attitude. Further, questionnaire research cannot provide a description or explanation of complex and interacting social, cultural, linguistic, and cognitive factors relating to behaviors and attitudes of teachers. Finally, questionnaire studies, because of their inherent flaws mentioned above, are often merely indicators of trends rather than true factual reflections of what actually is absolute truth. For this reason, extensive use of inferential statistics may be misleading.

\section{Suggestions for Future Research}

This study should be extended to focus on the beliefs of foreign language teachers in elementary and secondary school settings. Further studies on teacher beliefs should permit respondents to express their opinions about the content of individual items. A follow-up interview with some of the respondents would shed light on questionnaire responses. It would also be useful to find out the extent to which teacher beliefs are reflected in their actual teaching practice. Additionally, a study that would compare and match teacher and student belief systems would be another step in explaining effective foreign language teaching behaviors. Also, a continued line of research would compare groupings of foreign language teachers by language, years of experience, degree of education, and when teacher certification was completed in order to investigate whether, for example, a German teacher's pedagogy is more traditional than a Spanish teacher's, or whether a teacher who has been teaching for more than 25 years would have different attitudes toward foreign language teacher than a teacher who has only been teaching for 2 years. 


\section{Implications for Foreign Language Teacher Development and Evaluation}

The results of this study exploring teacher beliefs regarding effective foreign language teaching are of interest to numerous groups: foreign language teachers, administrators who work with foreign language teachers, teacher candidates who are preparing to teach, those who train prospective teachers, those responsible for the ongoing development of foreign language teachers, and those responsible for foreign language teacher evaluation. The results of the questionnaire are of interest to the foreign language teaching profession because they provide a glimpse of emerging consensus on those behaviors and beliefs which are perceived to be effective in foreign language teaching. All teachers can benefit from an awareness of emerging professional consensus regarding specific teaching behaviors that are believed to contribute to effective foreign language teaching and learning. By being made aware of these behaviors before they begin teaching, new teachers will be able to critically reflect on their own beliefs and teaching behaviors. It would be useful to discuss the questionnaire items that yielded high agreement among respondents in ongoing teacher development to make teachers aware of behaviors that experienced foreign language teachers (questionnaire respondents) believe to be effective in foreign language teaching. Teachers could be asked to react to certain items and reflect on what they believe to be effective teaching behaviors. It would also be useful to let teachers respond to a similar questionnaire and then compare their own responses to those of the study.

\section{Acknowledgments}

I am indebted to Professor Renate A. Schulz for her valuable and insightful comments on the penultimate draft of this manuscript.

\section{Notes}

1. This article reports the results of a dissertation study (Reber, 2001).

2. Only selected major findings of this study are reported in this article.

\section{References}

American Association of Teachers of French (AATF) (1989). The teaching of French: A syllabus of competence. AATF National Bulletin, 15, 1-35.

American Association of Teachers of Spanish and Portuguese (AATSP) (1990). AATSP program guidelines for the education and training of teachers of Spanish and Portuguese. Hispania, 73, 785-794.
American Council on the Teaching of Foreign Languages (ACTFL) (1988). ACTFL provisional program guidelines for foreign language teacher education. Foreign Language Annals, $21,71-82$.

Andrews, T. E., \& Barnes, S. (1990). Assessment of teaching. In W. R. Houston (Ed.), Handbook of research on teacher education: A project of the Association of Teacher Educators (pp. 569598). New York: Macmillan.

Asher, J. (1986). Learning another language through actions: The complete teachers' guidebook. Los Gatos, CA: Sky Oaks Productions.

Bragger, J. D., \& Rice, D. B. (1998). Connections: The national standards and a new paradigm for content-oriented materials and instruction. In J. Harper, M. Lively, \& M. Williams (Eds.), The coming of age of the profession: Issues and emerging ideas for the teaching of foreign languages (pp. 191-217). Boston: Heinle \& Heinle.

Brosh, H. (1996). Perceived characteristics of the effective language teacher. Foreign Language Annals, 29, 125-138.

Buck, K., Byrnes, H., \& Thompson, I. (Eds.). (1989). The ACTFL oral proficiency interview tester training manual. Yonkers, NY: ACTFL.

Bush, M., \& Terry, R. (Eds.). (1997). Technology-enhanced language learning. Lincolnwood, IL: National Textbook Co.

Carroll, S., \& Swain, M. (1993). Explicit and implicit negative feedback: An empirical study of the learning of linguistic generalizations. Studies in Second Language Acquisition, 15, $357-386$

Chaudron, C. (1988). Second language classrooms. Cambridge, UK: Cambridge University Press.

Curran, C. (1976). Counselling-learning in second languages. Apple River, IL: Apple River Press.

Curran, C. (1982). A linguistic model for learning and living in the new age of the person. In R. W. Blair (Ed.), Innovative approaches to language teaching (pp. 136-146). Rowley, MA: Newbury.

DeKeyser, R. M. (1993). The effect of error correction on L2 grammar knowledge and oral proficiency. Modern Language Journal, 77, 501-514.

Doughty, C., \& Williams, J. (1998). Focus on form in classroom second language acquisition. Cambridge, UK: Cambridge University Press.

Douglas, D. (1999). Assessing languages for specific purposes. Cambridge, UK: Cambridge University Press.

Dunkel, P. (Ed.). (1991). Computer-assisted language learning and testing: Research issues and practice. New York: Newbury House.

Ellis, R. (1994). Input and interaction and second language acquisition. In R. Ellis (Ed.) The study of second language acquisition (pp. 269-291). Oxford, UK: Oxford University Press.

Galloway, V. B. (1985). Communicating in a cultural context. Workshop given at the Northeast Conference Winter Workshop, Wakefield, MA.

Gattegno, C. (1972). Teaching foreign languages in schools: The silent way. New York: Educational Solutions. 
Genessee, F. (1998). Content-based instruction. In M. Met (Ed.), Critical issues in early second language learning (pp. 103-105). Glenview, IL: Scott Foresman-Addison Wesley.

Hancock, C. R. (Ed.) (1994). Northeast conference reports. Teaching, testing, and assessment: Making the connection (pp. 235-240). Lincolnwood, IL: National Textbook Co.

Kramsch, C. (1993a). Context and culture in language teaching. New York: Oxford University Press.

Kramsch, C. (1993b). Foreign language study as border study: Report on a cross-cultural teacher training seminar. Culture and content: Perspectives on the acquisition of cultural competence in the foreign language classroom, Monograph Series \#4. Tempe, AZ: Southwest Conference on Language Teaching.

Krashen, S. (1981). Second language acquisition and second language learning. Oxford, UK: Pergamon Press.

Krashen, S., \& Terrell, T. (1983). The natural approach: Language acquisition in the classroom. Oxford, UK: Pergamon.

Lado, R. (1964). Language teaching. New York: McGraw.

Lafford, P. A., \& Lafford, B. A. (1997). Learning language and culture with Internet technologies. In M. D. Bush \& R. M. Terry (Eds.), Technology-enhanced language learning (pp. 215-262). Lincolnwood, IL: National Textbook Co.

Lange, D. L. (1999). Planning for and using the new national culture standards. In J. K. Phillips \& R. M. Terry (Eds.), Foreign language standards: Linking research, theories, and practices (pp. 57-135). Lincolnwood, IL: National Textbook Co.

Larsen-Freeman, D. (1986). Techniques and practices in language teaching. Oxford, UK: Oxford University Press.

Leaver, B. L., \& Stryker, S. B. (1989). Content-based instruction for foreign language classrooms. Foreign Language Annals, 22, 269-275.

Lee, J. F., \& VanPatten, B. (2003). Making communicative language teaching happen. New York: McGraw Hill.

Liskin-Gasparro, J. (1996). Assessment: From content standards to student performance. In R. C. Lafayette (Ed.), National standards: A catalyst for reform (pp. 169-196). Lincolnwood, IL: National Textbook Co.

Lozanov, G. (1978). Suggestology and outlines of Suggestopedia. New York: Gordon \& Breach.

MacKay, R., \& Palmer, J. D. (1981). Languages for specific purposes: Program design and evaluation. Rowley, MA: Newbury House Publishers.

Merino, B. J., Trueba, H. T., \& Samaniego, F. A. (Eds.) (1993). Language and culture in learning: Teaching Spanish to native speakers of Spanish. London: Falmer.

Mitchell, R., \& Myles, F. (1998). Second language learning theories. London: Arnold.

Moore, Z. T. (1994). The portfolio and testing culture. In C. Hancock (Ed.), Northeast conference reports. Teaching, testing, and assessment: Making the connection (pp. 163-182). Lincolnwood, IL: National Textbook Co.

Murray, H. G. (1991). Effective teaching behaviors in the college classroom. In J. C. Smart (Ed.), Higher education: Handbook of theory and research, vol. 6 (pp. 135-172). New York: Agathon Press.
Murray, H. G., \& Renaud, R. D. (1995). Disciplinary differences in classroom teaching behaviors. In N. Hativa \& $\mathrm{M}$. Marincovich (Eds.), Disciplinary differences in teaching and learning: Implications for practice (pp. 31-40). San Francisco: Jossey Bass Publishers.

National Standards in Foreign Language Education Project (1999). Standards for foreign language learning in the 21st century. Yonkers, NY: Author.

Nunan, D. (1989). Designing tasks for the communicative classroom. Cambridge, UK: Cambridge University Press.

Pennington, M. C. (1996). The power of CALL. Houston, TX: Athelstan.

Reber, T. (2001). Effective teaching behaviors and attitudes as perceived by foreign language teachers. Doctoral dissertation, University of Arizona, Tucson.

Reber, T., \& Geeslin, K. (1998). An investigation of student opinions and educational experiences in Spanish for heritage speakers courses at Arizona State University and the University of Arizona. Texas Papers in Foreign Language Education, 3(2), 33-50.

Richards, J. C., \& Rodgers, T. S. (1986). Approaches and methods in language teaching. Cambridge, UK: Cambridge University Press.

Savignon, S. (1983). Communicative competence: Theory and practice. Reading, MA: Addison.

Savignon, S. J. (1998). Communicative competence: Theory and classroom practice. New York: McGraw Hill.

Schrier, L. L., \& Hammadou, J. (1994). Assessment in foreign language teacher education. In C. Hancock (Ed.), Northeast conference reports. Teaching, testing, and assessment: Making the connection (pp. 211-234). Lincolnwood, IL: National Textbook Co.

Schulz, R. A. (1988). Methods in teaching German in the United States: A historical perspective. In D. P. Benseler, W. F. W. Lohnes, \& V. Nollendorfs (Eds.), Teaching German in America: Prolegomena to a history (pp. 55-75). Madison, WI: University of Wisconsin Press.

Schulz, R. A. (2000). Foreign language teacher development: MLJ perspectives-1916-1999. Modern Language Journal, 84, 496-523.

Schulz, R., Anderson, K., Bernhardt, E., Byrnes, H., Cothrun, T. K., Dial, J. et al. (1993). Professional standards for teachers of German: Recommendations of the AATG task force on professional standards. Die Unterrichtspraxis, 26, 80-96.

Skinner, B. F. (1957). Verbal behavior. New York: Appleton.

Stansfield, C. W. (1994). Developments in foreign language testing and instruction: A national perspective. In C. Hancock, (Ed.), Northeast conference reports. Teaching, testing, and assessment: Making the connection (pp. 43-67). Lincolnwood, IL: National Textbook Co.

Sternberg, R. J., \& Horvath, J. A. (1995). A prototype view of expert teaching. Educational Researcher, 24(6), 9-17.

Valdés, G. (1995). The teaching of minority languages as academic subjects: Pedagogical and theoretical challenges. Modern Language Journal, 79, 299-328. 
VanPatten, B. (1992). Second language acquisition and foreign language teaching: Part 2. ADFL Bulletin, 23(3), 23-37.

Wiggins, G. (1989). A true test: Toward more authentic and equitable assessment. Phi Delta Kappan, 70(9), 703-713.

Wiggins, G. (1993). Assessment: Authenticity, context, and validity. Phi Delta Kappan, 75(3), 200-214.

Wiggins, G. (1994). Toward more authentic assessment of language performances. In C. Hancock (Ed.), Northeast conference reports. Teaching, testing, and assessment: Making the connection (pp. 69-85). Lincolnwood, IL: National Textbook Co. 